Journal of Law \& Social Studies (JLSS)

Volume 1, Issue 1, pp 45-51

www.advancelrf.org

\title{
Access to Essential Medicine: Making a Case for Compulsory Licensing of Pharmaceutics in Pakistan
}

\author{
Syeda Tooba Akhtar \\ College of Law, University of Sargodha \\ tooba.akhtar@uos.edu.pk \\ toobakhtar@gmail.com
}

\begin{abstract}
Access to essential medicine has been a serious issue in the low income countries. Statistics show that many a patient dies in Pakistan due to lack of access to essential medicine. Pakistan is member of World Trade Organization. It fulfills its obligations towards protection of intellectual property right and by well formulated rules and policies. However, the well being of its people with regard to health represents a grave scenario. After establishing the fact of appalling scenario of health on one hand and the growth of pharmaceutical industry on the other the study highlights the flexibilities in international legal regime against monopolistic practice of patent holder. It discusses some of the instances of grant of Compulsory Licensing. After examining the legal frame work of Pakistan, it concluded in favour of grant of Compulsory Licensing in appropriate cases without risking its obligation under WTO.
\end{abstract}

Keywords: WTO, Intellectual Property Rights, Compulsory Licensing, Pharmaceutical Industries

\section{Introduction}

After adoption of Intellectual property laws in consonance with her international obligations, Pakistan witnessed a tremendous growth in its sector of pharmaceutics. As of 2015, Pakistan has approximately 400 manufacturing units of Pharmaceutics. There are almost 25 Pharmaceutical manufacturing units that are managed and owned by multinationals. Over the years, national pharmaceutical industry has shown progressive growth in terms of number of medicine produced and profits earned by these pharmaceutical groups. Its exports are now worth \$US200 million with expectation of gradual increase on yearly basis. It was argued that $70 \%$ consumed medicines are produced in Pakistan by both national and multinational pharmaceutical industries but still there is ever widening gap between the need and access to essential medicine. It was concluded that use of counterfeit medicine comprised of $40-50 \%$ of total usage in Pakistan. Inaccessibility, the high prices of genuine pharmaceutical products is the prime reason behind the use of counterfeit medicine.

The Drug Regulatory Authority of Pakistan (DRAP) has, after taking due approval from federal government, allowed $15 \%$ increase in the price of almost 24,000 medicines including life saving drugs such as medication for brain disease, cancer and post surgical drugs. DRAP maintained that shortage of medicine on account of less attractive price for the manufacturer was the legitimate compelling factor behind this price hike.

This gap of growth of pharmaceutical sector on one hand and inaccessibility of essential medicine on the other hand to a large number of populations in Pakistan, is the key point of this research whereby this study argues in favour of Compulsory Licensing of pharmaceutical patents in Pakistan without compromising its international obligations with regard to the protection of intellectual property rights.

According to the definition given by World Trade Organization (WTO) Compulsory Licensing is the grant of permission by the relevant authorities of a state to produce and sell a particular kind of product without the consent of the patent holder. This license may be granted to any government agency or any other company upon terms and conditions mentioned in the then prevailing law.

\section{Protection of Intellectual Property Rights}

In $21^{\text {st }}$ century, Protection of Intellectual Property Rights (IPR) is inevitable for over-all progress and growth of a state. The economic prosperity of a country is dependent upon how it protects and safeguards the rights of any inventor. The existence of a strong legal framework for the fortification of IPR has far reaching positive impact on the foreign 
direct investment for any state. Inadequate and feeble system of protection deters foreign investors. The impact of a weak system may be more devastating in technology-intensive sectors that rely heavily on IPR.

It was believed that undertaking research and development in states with inadequate IPR regimes is awfully unattractive. Protection of one's effort is one of the major encouraging factors behind research and development in almost every field. Scrawny IPR results in low returns to innovation and improvements. Underutilization of original and innovative talent is may be one of the adversaries.

Moreover, it was argued that developed countries tend to pay more attention to the protection of IPR as their overall economic growth and progress is dependent upon research and development to a great extend. The patent system works as a catalyst to expedite technological advancement. It works as the booster for productivity and helps to improve the trade status of any state at international level.

A good number of studies with respect to the protection of IPR suggested that protection of patents is significantly more important to the pharmaceutical industry as compared to the other hi tech sector. The principal reason for its being comparatively more important in the pharmaceutical sector is that the cost of research and development is greater than the same cost in other fields of technology. It was believed that grant of exclusive right even for a specified period of time to the inventors facilitate them to reasonably recover their cost of invention and works as an incentive for future researches. Research and development in the pharmaceutical sector of Italy increased $600 \%$ within a decade of adoption of drug patent laws in 1978.

Moreover it is inherent in human nature that one on like the unauthorized use piracy of his intellectual creation. Hence, patent protection is accepted as a necessary evil. Pakistan joined World Trade Organization (WTO) in 1995 and also a signatory to Trade-Related Aspects of Intellectual property Rights (TRIPS). TRIPS is an international agreement between all the members of WTO for the protection of IPR and encouraging the innovative approach in all sectors generally and pharmaceutics in particularly. It introduces minimum standard of protection extended to almost all types of IPR. It further obliges all the member states of WTO of adopt patent related enactment in line with TRIPS. Prior to the conclusion of TRIPS, different countries provided patent protection for a different length of time. In some developing countries patent protected was available only for a period of 3 to four years. But by virtue of TRIPS, the minimum time period for the protection of patent is 20 years.

\section{Compulsory Licensing: an overview}

According to WHO, approximately 14 million people in developing countries die of poverty associated infectious diseases such as HIV/AIDS, diarrhea, malaria and tuberculosis. The required target medicines for these diseases are often available. Unfortunately, the patients in developing countries simply cannot afford to buy them owing to high prices of these essential medicine protected under law of patents. Consequently, access to medicine is a critical issue in low income developing or under develops countries. In such a situation, they usually look up to WHO for support in this regard.

Patent protection though apparently appears to be in violation of human rights but the above part of this study affirms it as one of the necessary evil to be adopted to run the race from developing to developed countries. No doubts, there are instances of misuse of patent protection by the holder of patent in order to achieve financial gains. Nonetheless, the very TRIPS agreement contains flexibilities that can be legitimately exploited by the member states of WTO in order to meet their responsibilities towards their citizens.

Abbas (2013) argued that higher prices of drugs is primarily due to monopoly given to the patent holder whereby they tend to grab more and more financial benefits at the cost of suffering humanity. He further contended that perhaps initially TRIPS agreement was concluded in oblivion of outbreak of epidemics like HIV/AIDS in third world countries. Moreover, the public health issues were not given due importance in comparison with the protection of an intellectual property invention. Nonetheless, according to WTO, the flexibility of Compulsory Licensing was available in the said agreement since it took effect in January, 1995.

There are certain recent examples of the countries that invoke the flexibility of CL to protect its citizens from the mere profit oriented approach by some pharmaceutical companies In January, 2007 the Government of Thailand issued Compulsory Licensing against the patent of two type of medicine of Abbot Laboratories. This did not happen all of sudden. The Swiss and US Ambassadors tried their level best to stop the government from issuing this Compulsory Licensing. In May, 2007 after failure of rounds and rounds of talks with the relevant pharmaceutical patent holder 
company, the government of Brazil through presidential order issued Compulsory Licensing for a drug used to treat cancer. These instances of Compulsory Licensing were widely criticized by the advocates of protection of IPR and the pharmaceutics association all over the world. However, the usefulness of grant of Compulsory Licensing in Brazil and Thailand cannot be underestimated keeping in view the legitimate attempt to protect public health against the abusive exploitation of patent.

In March 2012, India made headlines around the globe by granting its first ever compulsory license of pharmaceuticals to its local pharmaceutical company Natco Pharma Ltd to produce and sell life extending drug called 'Sorafenib' for kidney and liver cancer. This compulsory license was extended against a patent for 'Bayer a US based pharmaceutical company. After this first episode of Compulsory Licensing, huge diplomatic pressure was mounted on India by US and other developed countries. Nonetheless, the authority successfully maintained its arguments in the Indian Supreme Court that the license was issued for the public need have not been fulfilled by the patent holder. The price of the drug incredibly went down from Rs 280,420 to Rs $8800 /-$.

Despite global reaction on account of above mentioned instance of Compulsory Licensing, India did not stop here. In 2013, India shocked its pharmaceutics industry by denying patent to cancer curing drug to a renowned Swiss pharmaceutical company "Novartis". The patent was denied by the Supreme Court of India on ground of incremental modification in the already available version. As a matter of fact, it is well settled tactic on the part of big pharmaceutical company to extend the duration of its existing patent.

In 2001, when USA was under anthrax attack, the price of antrax medication ciprofloxacin was required to be reduced in order to make it accessible to a large number of people. The then US Government warned in clear words to issue Compulsory Licensing of the said antibiotic if Bayer, the patent owner, did not lower the price. However, the threat worked and Bayer reduced the price.

The above mentioned instances of Compulsory Licensing were widely criticized. Rather certain alleged it to be such a dangerous practice on the part of developing countries potential enough to hamper the overall growth and progress of these countries. But the international legal regime does not protect commercial or trade rights at the cost of well being of humanity. Of course, welfare of people is priority. UN Commission on Human Rights expressed its concerns about the patent protection granting monopoly to the patent holder over its product. Through its resolution, it was expressed that there exist an apparent conflict between human rights and IPR protected extended through TRIPS. The concern was expressed on the instances of sky high prices of essential medicine in low income countries where pharmaceutics were believed to reap undue financial advantage on account of monopoly granted under the umbrella of patent protection.

However, the remedy against monopolistic practice has been granted by TRIPS agreement in itself. The flexibility of Compulsory Licensing is given in Article 31 TRIPS agreement. Some believe it to be addition made at Doha Declaration 2001. But this very article was the part of the agreement since it took effect in 1995. Doha Declaration just assured the flexibilities to be used at the discretion of the government of the least developed countries keeping in view their state based issues and circumstance. Moreover, WTO does not recognize Compulsory Licensing as the violation of the patent. By virtue of Article 31, the patent holder continues to have right over it. The patent holder has the right to be paid on the sale of the copies of the product for which the Compulsory Licensing was granted (WTO).

Hence, WTO did cover the humanitarian aspects of the IPR through the above discussed flexibilities. It is pertinent to mention here that TRIPS agreement attempted to cover the misuse of the fallibility of Compulsory Licensing as well. In order to avoid Compulsory Licensing to be used for undue commercial gains, these flexibilities have been expressly allowed to be availed to meet the need of domestic market only and not for export purpose. An interesting scholarly debate can be offered about it but this very point does not come within the scope of this study.

\section{Access to essential medicine}

The preamble to the Constitution of World Health Organization (WHO) obliges the states to have a joint declaration by the signatories with respect to higher standard of health care of their citizens. It defined the right of health of an individual to be in a condition of complete physical, mental and social well-being. It does not confine the definition of health to a mere the absence of disease or any frailty. It declares that provision of highest achievable standards with regard to health is one of the fundamental rights of every human being without distinction of race, religion, and political belief, economic or social condition. The Constitution unequivocally places the governments under 
responsibility to maintain the health of their citizen through the appropriately adopted measures. It states that the advantages of progress in the knowledge for the overall medical well being of the citizen should be extended for all.

Article 25 of the Universal Declaration of Human Rights 1948 recognizes the adequate standards of health as one of human rights for an individual and his family. International Covenant on Economic, Social and Cultural Rights, 1966 vide Article 12 reaffirms this right to the highest achievable degree of physical as well as mental health. This right to health as one of the most fundamental rights of human being all over the world has been affirmed in a number of international conventions including Convention on Elimination of all Forma of Racial Discrimination against Women and Convention on Rights of Child.

Discussing this right of health at national level, the Constitution of Pakistan, 1973 proclaimed in its article 38 that the states shall be responsible for the well being of citizen irrespective of discrimination on any ground. This Article mentions the provision of medical facilities as one of the basic necessities of life. Hence the Government of Pakistan is has a dual obligation both national and international level to provide basic medical facilities.

Pakistan, the sixth most populated country in the world, has a population of 199.71 millions where an estimated 34.2\% of people are living below the poverty line (Pakistan Economic Survey, 2016-2017). Pakistan ranked $7^{\text {th }}$ in cancer related deaths (The News, Oct 9, 2018). Approximately 33\% of population above the age of 45 is hypertensive. Liver diseases like Hepatitis $\mathrm{C}$ are at their high. Every $9^{\text {th }}$ resident of Pakistan is suffering from liver disease of any type. With respect to diabetes Pakistan ranks number $6^{\text {th }}$ in the world. The rate of heart disease death is $34 \%$ of the total deaths. The concerns were expressed about various emerging viral infections in Pakistan. Access to essential medicine has been a serious issue in Pakistan that results in the grave health scenario. It was concluded that poverty is directly related to health conditions of the populace. Health standards of the citizens of low income Countries can only be improved through the pro people approach of their political regimes.

In order to provide a better health care system and access to medicine, Pakistan developed proper system of rules and regulations regarding Pharmaceutics as an industry and for price regulations as well. Pakistan being member of WTO and signatory to TRIPS has adequate laws and system in order to meet its international obligations and to fulfill its duty of protecting well being of citizen. On account of a well organized regulatory system, the growth of pharmaceutical industry in Pakistan along with its share in exports has already been discussed in the introductory part of this study. The industry is on its way to progress but the health standards are decaying day by day. The dismaying fact of use of counterfeit medicine comprising of 40-50\% of total usage in Pakistan is also one of the stimulant for the sharp decrease in the health of people of Pakistan.

Admittedly, high price or unavailability may be the compelling factors behind the use of counterfeit drugs. Again, the pharmaceutical industry is on its way to increase its share in the export. But the domestic user is the victim of either price hike or shortage of the required drug. None of the pharmaceutical plants operating in Pakistan is FDA approved. Nadeem BJ Sheikh, director CCL Pharmaceutical, confessed the lack of standardized plants and lack of invest on part of pharmaceutical industry to invest in research and development as one of the reason behind it. On the other hand, DRAP recently notified $15 \%$ increase in the prices of a good number of drugs because of pressure from the industry. DRAP had to succumb to the pressure as the patients were suffering owing to shortage of these medicines.

This does not mean that the entire pharmaceutics sector in Pakistan is indifferent to the suffering humanity. There is an interesting example of efforts of the joint efforts of Provincial Government of Khyber Pakhtunkhwa and pharmaceutical company Novartis. In Hayatabad Medical complex, the Oncology Unit gets more than 1,000 new patient of cancer. Since 2012, more than approximately 5,000 patients have been provided free treatment under the cost sharing programme of worth Rs. 20 billion in which Novartis has contributed Rs.17.73 billion and the Government has the contribution of Rs 1.86 billion. Almost $80 \%$ of the patients of the cancer treated under this programme have the monthly income of less than Rs. 20,000. This joint venture to help the poor people of Pakistan is appreciate-able. However, the answer to the question that should Government of Pakistan merely rely on the philanthropic approaches in the matter of access to medicine require separate and detailed research based discussion.

It is utmost duty of any state to secure the well being of its citizens. From the above discussion it is quite clear that Pharmaceutical Industry in Pakistan is in advantageous position at the cost of the poor patient. The pharmaceutical companies operating in Pakistan need to develop a balance between patient and profit. It is high time that government of Pakistan should negotiate with the pharmaceutical sector to make them realize their social duty. In case of failure, this study expressly urges Government of Pakistan to opt for Compulsory Licensing in the greater interest of its population. 


\section{Compulsory Licensing in the legal framework of Pakistan}

As discussed earlier, Pakistan has an adequate system of rules and regulations in order to protect IPR in consonance with its obligation under international regime of IPR. Pakistan has Patent Act 2000 that provides for in detail procedure for the registration and further protection of IPR. Under the said Act the patent holder has the duration of 2 years to enjoy the protection of its intellectual effort to the exclusion of others in matter of production, marketing or stocking etc. These exclusive monetary benefits work as incentive for the putting more and more efforts to the research and invention at both individual and collective level.

In line with flexibilities offered by TRIPS agreement, Article 58 of Chapter 16 of the Patent Ordinance 2000 provides for authority of the government authority to issue Compulsory Licensing under the circumstance adequately detailed therein. According to Article 58 sub section 1, the following are the circumstance when the Federal Government of Pakistan may invoke this provision;

a) Where it is pertinent to do so in the in the particular interest of public, nutrition, health, national security or for the development of other vital sector of the economy

b) When there is anti competitive exploitation of the invention on the part of patent holder

c) Where the patent holder failed to exploit it in the manner that contribute to the technological advancement.

d) Where the patent holder refused to grant the license on reasonable commercial terms.

Sub-section 2 of the Article 58 binds the Federal Government to afford an opportunity of hearing on the desire of any person interested therein. The Government cannot proceed to issue Compulsory Licensing without giving this opportunity. Moreover, the request for authorization of Compulsory Licensing must accompany the evidence of failure of grant of the permission from patent holder upon reasonable terms and condition. Nonetheless, this condition shall not be applicable in the cases of national emergency, determination of anti-competitive practice through competent judicial or administrative body or public non-commercial use. In fact these are the circumstances that warrant expedition in terms of time.

This grant of license may be to any government agency itself or to the any third party upon the application fulfilling the requirements set out in Patent Ordinance 2000. According to section 59, any person claiming the license has to satisfy the Controller of Patents (CP) of regarding in-sufficient or non-exploitation of on the part of patent holder. But this is genuinely countered by patent holder if he satisfies the Controller of Patents as to the inevitable circumstance that led to the non-exploitation or in-sufficient exploitation of his patent. It is significant to mention here that the grant of Compulsory Licensing under the Ordinance is limited to meet the needs and demand of the domestic market only. Moreover, the decision of Federal Government for grant of Compulsory Licensing is subject to appeal to High Court.

Hence, the grant of Compulsory Licensing is not an unbridled opportunity to the disadvantage of IPR. The analysis of the provision of Patent Ordinance 2000 makes it clear that it is not for the disadvantage of the patent holder but for monopolistic practice and insufficient exploitation. Pakistan may secure the better health and well being of its citizen within the scope of legal frame work.

\section{Conclusion}

After going through the arguments of this study, it can be concluded that the Government of Pakistan may protect the wellbeing of its people without piecing the international obligations. The appalling health scenario in Pakistan demands immediate steps to be taken by the Government of Pakistan. On one hand, there are instance of time and again hike in the prices of essential drugs on the request of pharmaceutical industries trough the legitimate process by DRAP. On the other hand people of Pakistan are sufferings from the in-access essential medicine. They are compelled to use counterfeit drugs on account of shortage or sky high prices of these medicines. Securing the well being of the citizen is the prime duty of State. This duty can be performed effectively by the Federal Government by invoking the provisions of Compulsory Licensing within the legal frame work of Pakistan. It is quite clear that the provisions of Compulsory Licensing are in accordance with TRIPS agreement. Therefore, some authors do not see Compulsory Licensing as disadvantageous for IPR. As a matter of fact both IPR and Compulsory Licensing are for the benefit of mankind. Both aim at serving the humanity. Prioritizing the welfare of maximum number of people is the need of hour.

\section{References}


Abbas, M. Z. (2013). Pros and cons of compulsory licensing: An analysis of arguments. International Journal of Social Science and Humanity, 3(3), 254-258.

Asif, M., and Awan, M. (2005). Pakistani pharmaceutical industry in WTO regime, Issues and prospects. Journal of Quality and Technology Management, 1(1), 21-34

Bonadio, E. (2012). Compulsory licensing of patents: the Bayer/Natco case. Natco Case, 719-728.

Cheema, A, J. (2015). Patent and lifelines. The Nation, https://nation.com.pk/28-Sep-2015/patents-and-lifelines accessed on 12-02-2016

Convention on Elimination of All form of Racial Discrimination Against Women 1979

Grabowski, H. (2002). Patents, innovation and access to new pharmaceuticals. Journal of International Economic Law, 5(4), 849-860.

Guennif, S. (2017). Evaluating the usefulness of compulsory licensing in developing countries: a comparative study of Thai and Brazilian experiences regarding access to AIDS treatments. Developing world bioethics, 17(2), 90-99.

Harris, D. (2010). TRIPS after fifteen years: Success or failure, as measured by compulsory licensing. J. Intell. Prop. L., 18,367 .

Intellectual Property and Human Rights, United nations Sub-Commission on Human Rights. https://undocs.org/E/CN.4/Sub.2/2001/21 accessed on 10-02-20198

International Covenant on Economic, Social and Cultural Rights, 1966.

Jamshed, S. Q., Malik, M. A., Löfgren, H., \& Gilani, A. H. (2013). The pharmaceutical industry, intellectual property rights and access to medicines in Pakistan. In The New Political Economy of Pharmaceuticals, Palgrave Macmillan, London, 167-184.

Julian-Arnold, G. (1993). International compulsory licensing: the rationales and the reality. Idea: The Journal of Law and Technology, 33, 349.

Khalil, A. T., Ali, M., Tanveer, F., Ovais, M., Idrees, M., Shinwari, Z. K., \& Hollenbeck, J. E. (2017). Emerging viral infections in Pakistan: issues, concerns, and future prospects. Health security, 15(3), 268-281.

Kremer, M. (2002). Pharmaceuticals and the developing world. Journal of Economic Perspectives, 16(4), 67-90.

Löfgren, H., \& Williams, O. (Eds.). (2016). The new political economy of pharmaceuticals: production, innovation and TRIPS in the global south. Springer.

Mahmood, Z., \& Kazmi, A. A. (1998). WTO and Pakistan: Opportunities and Policy Challenges [with Comments]. The Pakistan Development Review, 687-701.

Mahmood, Z., \& Kazmi, A. A. (1998). WTO and Pakistan: Opportunities and Policy Challenges [with Comments]. The Pakistan Development Review, 687-701.

National Heath Survey. (2011). https://www.shifa.com.pk/chronic-disease-pakistan/ accessed on 08-02-2018

Pakistan health affairs. (2018). https://www.thenews.com.pk/print/378356-pakistan-ranked-7th-in-cervical-cancerdeaths accessed on 10-05-2018

Pakistan: Poverty reduction strategy paper. (2010). International Monetary Fund.

Patent Ordinance 2000

Reichman, J. H. (2009). Comment: compulsory licensing of patented pharmaceutical inventions: evaluating the options. The Journal of Law, Medicine \& Ethics, 37(2), 247-263.

Smarzynska, B. (2002). The composition of foreign direct investment and protection of intellectual property rights: Evidence from transition economies. The World Bank.. 
Tariq, T. (2018). Pak Pharma Industry Suffers from Government Shackles. https://profit.pakistantoday.com.pk/2018/02/06/pak-pharma-industry-suffers-from-governments-shackles/ accessed on 10-04-2018

The Constitution of Pakistan, 1973

The Law of Patents in Pakistan (2001, November 19)

TRIPs \& Access to Medicines. A Choice between Patents and Patients! (2010; 12 pages) available at http://apps. who.int/medicinedocs/en/m/abstract/Js18047en/

Universal Declaration of Human Rights 1948.

World Health Organization (WHO) Constitution (1946)

World Trade Organization. https://www.wto.org/english/tratop_e/trips_e/public health_faq_e.htm accessed on 1002-2018

Zaidi, S., \& Nishtar, N. (2011). Access to essential medicines: in Pakistan identifying policy research and concerns.

Zhao, M. (2006). Conducting R\&D in countries with weak intellectual property rights protection. Management Science, 52(8), 1185-1199. 